\title{
IgA-anti-yersinia antibodies in yersinia triggered reactive arthritis
}

\author{
KAISA GRANFORS, ${ }^{1}$ AND AULI TOIVANEN ${ }^{2}$ \\ From the Departments of ${ }^{1}$ Medical Microbiology and ${ }^{2}$ Medicine, Turku University, Turku, Finland
}

SUMMARY Patients who develop reactive arthritis after yersinia enteritis are characterised by high and persisting IgA-anti-yersinia antibodies. We have further analysed the humoral immune response to yersinia in this condition. Total concentrations of $\operatorname{IgM}, \operatorname{IgG}, \operatorname{IgA}$, and secretory $\operatorname{IgA}$ in the serum and specific anti-yersinia antibodies belonging to $\operatorname{IgA} 1, \operatorname{Ig} \mathrm{A} 2$, or secretory $\operatorname{IgA}$ were compared in patients with or without reactive arthritis. In the former group the serum concentration of secretory $\operatorname{IgA}$ and of yersinia specific antibodies in all categories studied was raised compared with the level in patients without joint symptoms; the difference was most significant for the $\operatorname{IgA}$-anti-yersinia antibodies with secretory piece or with $\mathrm{J}$ chain. The findings suggest that the strong antibody response in the patients developing reactive arthritis is due to a chronic stimulation of the intestinal lymphoid tissue.

The most common symptoms of yersinia infection are fever, abdominal pain, and gastroenteritis. ${ }^{12}$ The disease is often mild and may even pass unnoticed. One to three weeks after the initial phase, however, postinfection complications such as eye inflammation or arthritis may develop. Yersinia triggered reactive arthritis varies in severity from slight arthralgias to severe polyarthropathies and in duration from a few days to several months; in some cases chronic arthropathies develop. ${ }^{3-6}$

In the pathogenesis of yersinia triggered reactive arthritis the micro-organism is the main causative factor, and some strains of yersinia are especially prone to give rise to postinfection complications. ${ }^{7}$ Host related factors are also of obvious importance. The risk of complications is much increased in persons with HLA-B27. ${ }^{38}$ Also, the immune response of patients developing reactive arthritis differs from that in persons who recover from a yersinia infection without complications. Thus the proliferative response of lymphocytes to yersinia or Escherichia coli is weaker in patients with arthritis despite otherwise normal cell mediated immune competence. ${ }^{9-11}$ Patients with arthritis tend in the initial phase to have a weak antibody response of IgM class against yersinia, but later they show a strong and persisting IgG and especially $\operatorname{IgA}$ re-

Accepted for publication 28 January 1986.

Correspondence to Dr Kaisa Granfors, Department of Medical Microbiology, Turku University, SF-20520 Turku, Finland. sponse, which may even last for years after the actual disease; the serum levels of $\operatorname{IgA}$ antibodies to yersinia seem to correlate with the severity of the arthritis. $^{1213}$

The strong IgA response to yersinia in arthritic patients is an interesting phenomenon since the half life of $\operatorname{IgA}$ is only a few days ${ }^{14}$; therefore the persistence of yersinia specific IgA suggests prolonged stimulation and continuous antibody production. It is an open question where this production takes place. We have approached the question by quantifying separately the $\operatorname{IgA} 1, \operatorname{Ig} A 2$, and secretory $\operatorname{IgA}$ antibodies to yersinia in patients with or without reactive arthritis after yersinia enteritis. The results obtained suggest strongly that substantial production of the anti-yersinia antibodies in patients with reactive arthritis takes place locally in the intestinal mucosa or close to it.

\section{Patients and methods}

PAT IENTS

A total of 125 serum samples from 42 patients with yersinia infection was studied. Yersinia enterocolitica serotype O:3 infection was diagnosed on the basis of bacteriological or serological findings, or both, and the typical clinical picture. The patients were divided into two groups according to their arthritic symptoms. Eighteen patients developed arthritis after yersinia infection. All of them had clearly demonstrable joint effusion in at least one joint. 
Twenty four had no arthritic symptoms. Serum samples were collected from the patients, starting from the beginning of the infection. The follow up periods ranged from two to 12 months after onset of the infection, with a mean interval of 1.3 months between the samples. All samples were stored at $-20^{\circ} \mathrm{C}$ and studied at the same time.

ELISA FOR YERSINIA ANTIBODIES CONTAINING SECRETORY COMPONENT AND J CHAIN

Antibodies to yersinia containing secretory component and $J$ chain were measured by an enzyme linked immunosorbent assay using the same principle as described earlier for IgM, IgG, and IgA class yersinia antibodies. ${ }^{12}$ In brief, yersinia antigens were adsorbed onto polystyrene microtitre plates (Linbro, Titertek, Linbro Division, Flow Laboratories, Hamden, Conn.); $75 \mu \mathrm{l}$ volumes of serum dilutions $(1: 100)$ were added to the plates and incubated at $37^{\circ} \mathrm{C}$ for two hours. The plates were washed three times with saline containing $0.05 \%$ Tween 20 , and $75 \mu \mathrm{l}$ of rabbit immunoglobulins to human secretory component (fluorescein isothiocyanate conjugated, DAKO Patts A/S, Copenhagen, Denmark) in dilution 1:300 or to human $\mathrm{J}$ chain (Nordic Immunological Laboratories, Tilburg, Netherlands) in dilution 1:1500 was added. After incubation overnight at room temperature washing was carried out as previously, and alkaline phosphatase conjugated swine antirabbit IgG (Orion Diagnostica, Espoo, Finland) was added in dilution $1: 400$ and incubated at $37^{\circ} \mathrm{C}$ for five hours. After three repeated washings $75 \mu \mathrm{l}$ fresh substrate $(1 \mathrm{mg}$ of the disodium salt of $p$-nitrophenyl phosphate/ml of diethanolamine- $\mathrm{MgCl}_{2}$ buffer solution; Orion Diagnostica) was added to the plates, which were then incubated for $30 \mathrm{~min}$ at $37^{\circ} \mathrm{C} ; 120 \mu \mathrm{l}$ of $1 \mathrm{M} \mathrm{NaOH}$ was added to stop the reaction. The optical absorbance was measured by a specially designed photometer (Titertek/Multiskan, Eflab, Helsinki, Finland) at a wavelength of $405 \mathrm{~nm}$. The results were evaluated by means of standard sera containing high concentrations of the corresponding yersinia antibodies. The concentration of antibodies in the sample was expressed as relative units (EIU), where one unit was $1 / 100$ of the corresponding antibody concentration in the reference serum.

ELISA FOR IgA1 AND IgA 2 YERSINIA ANTIBODIES

For the measurement of $\operatorname{IgA} 1$ and $\operatorname{IgA} 2$ antibodies to yersinia monoclonal antibodies against the two IgA subclasses were used in an ELISA with yersinia antigen. After incubation of serum dilutions (1:100) on yersinia antigen coated plates monoclonal antibody against IgA1 or IgA2 (Becton and Dickinson Co., Sunnyvale, California; clone 1-155-1, code No 5100 and clone $14-3-26$, code 5110 respectively) was added onto the plates separately at a dilution of 1:500. After incubation and washing rabbit FITC conjugated antimouse immunoglobulin (MilesYeda, Kiryat Weizmann, Rehovot, Israel) absorbed with human IgG was added at a dilution of 1:2000 and incubated for three hours. After washing alkaline phosphatase conjugated swine antirabbit IgG (Orion Diganostica) was added and the enzyme reaction was allowed to occur as described before. The results were evaluated by means of standard sera as described above for secretory $\operatorname{IgA}$ antibodies.

TOTAL I gM, IgG, AND I gA

Total serum IgM, IgG, and IgA were measured with Tripartigen plates (Behringwerke, Marburg, West Germany).

QUANTIFICATION OF TOTAL SECRETORY IgA The total amount of secretory $\operatorname{IgA}$ was determined by an ELISA. Polystyrene microtitre plates (Linbro) were coated with antihuman IgA (Cappel Laboratories, Cochranville, Pennsylvania, USA). After incubation overnight the antibody solution was emptied from the wells and the samples to be assayed, diluted 1:50 in 1\% normal sheep serum/ PBS, were incubated in the plates for two hours at $37^{\circ} \mathrm{C}$. Washing was carried out three times as above, and rabbit immunoglobulins to the human secretory component (FITC conjugated, DAKO Patts A/S) were added in dilution 1:300. After incubation overnight at room temperature washing was carried out as previously and alkaline phosphatase conjugated swine antirabbit IgG (Orion Diagnostica) was added in dilution $1: 400$ and incubated at $37^{\circ} \mathrm{C}$ for five hours. After washing substrate was added, absorbances measured, and results evaluated by means of the standard serum as described above for secretory $\operatorname{Ig}$ A yersinia antibodies.

TESTING THE SPECIFICITY OF THE ANTISECRETORY PIECE REAGENT

The key issue in evaluating the results is the specificity of the antisera used as detecting reagents, and therefore they were tested extensively. We were especially concerned about the possibility that the antisecretory piece reagent might also pick up antiyersinia antibodies of monomeric IgA. This was ruled out by testing the specificity of the antisecretory piece reagent in the following way. Serum samples from four patients giving a positive reaction in an ELISA for IgM, IgG, and IgA yersinia 
antibodies and for secretory $\operatorname{IgA}$ yersinia antibodies were centrifuged in sucrose density gradients (5$40 \%$ sucrose) at $156000 \mathrm{~g}$ for 16 hours (Beckman, model L2-65B). Twenty eight fractions collected through the bottom of the tubes were quantified by an ELISA separately for $\operatorname{IgM}, \operatorname{IgG}, \operatorname{IgA}$, and secretory IgA antibodies to yersinia. Measurement of IgM, IgG, IgA, and secretory IgA antibodies to yersinia in each fraction showed different sedimentation constants characteristic for each of them. The antisecretory piece reagent gave a peak between $\operatorname{IgM}$ and $\operatorname{IgA}$, characteristic for polymeric $\operatorname{IgA}$. No reactivity with this reagent was seen in the area of peaks of $\operatorname{IgM}, \operatorname{IgG}$, or IgA. The FITC conjugated antisecretory piece reagent (DAKO Patts A/S, Copenhagen, Denmark) was the only one out of six antisecretory piece reagents available which was specific for polymeric IgA. All unconjugated reagents tested reacted also with monomeric IgA. The presence of the FITC label did not disturb our ELISA.

\section{Results}

\section{TOTAL IMMUNOGLOBULIN}

The total concentrations of serum IgM and IgG were similar in both patient groups (Table 1). The total concentrations of serum IgA were slightly higher in patients with reactive arthritis, but the difference was not statistically significant. When the secretory $\operatorname{IgA}$ was analysed separately the difference between these two patient groups was clear: in arthritic patients the concentration was $86 \cdot 8 \pm 12 \cdot 2$ EIU (mean $\pm S E M)$ and in those without arthritis $36 \cdot 2 \pm 19 \cdot 5$ EIU $\left(p<0 \cdot 05, \chi^{2}\right.$ test $)$.

\section{YERSINIA ANTIBODIES}

The concentrations of yersinia specific antibodies belonging to secretory IgA, molecules containing $\mathrm{J}$ chain, $\operatorname{IgA} 1$, or $\operatorname{IgA} 2$ are given in Table 2. A similar difference between the two patient groups is clearly

Table 1 The highest $\operatorname{Ig} M, \lg G, \operatorname{Ig} A$, and secretory $\operatorname{Ig} A$ concentrations measured during the follow up in sera of patients after $Y$ enterocolitica $O: 3$ infection, according to the presence of arthritis

\begin{tabular}{llllll}
\hline Arthritis & $\begin{array}{l}\text { IgM } \\
(\mathrm{mg} / \mathrm{ml})\end{array}$ & $\begin{array}{l}\lg (\mathrm{mg} / \mathrm{ml}) \\
(\mathrm{mg} / \mathrm{ml})\end{array}$ & $\begin{array}{l}\text { IgA } \\
(\mathrm{m})\end{array}$ & $\begin{array}{l}\text { Secretory } \\
\text { (EIU) }\end{array}$ & $\begin{array}{l}\text { No of } \\
\text { patients }\end{array}$ \\
\hline No & $2 \cdot 3 \pm 0 \cdot 4^{*}$ & $14 \cdot 6 \pm 0 \cdot 5$ & $3 \cdot 1 \pm 0 \cdot 3$ & $36 \cdot 2 \pm 19 \cdot 5$ & 11 \\
Yes & $2 \cdot 2 \pm 0 \cdot 3$ & $16 \cdot 9 \pm 0 \cdot 9$ & $4 \cdot 0 \pm 0 \cdot 3$ & $86 \cdot 8 \pm 12 \cdot 2$ & 15 \\
& NS & NS & NS & $\mathrm{p}<0 \cdot 05$ & \\
\hline
\end{tabular}

*Values are mean $\pm \mathrm{SEM}$. NS $=$ not significant.
Table 2 The highest concentrations of yersinia specific antibodies belonging to secretory IgA, J chain containing antibodies, IgA1, or IgA2 measured during the follow up in sera of patients after Y enterocolitica $O: 3$ infection, according to the presence of arthritis

\begin{tabular}{lrrrll}
\hline Arthritis & \multicolumn{2}{l}{ Yersinia } & antibodies & $\left(E I U^{*}\right)$ & \multirow{2}{*}{$\begin{array}{l}\text { No of } \\
\text { patients }\end{array}$} \\
\cline { 2 - 5 } & \multicolumn{1}{c}{ slgA } & J chain & IgA1 & IgA2 & \\
\hline No & $61 \pm 10^{+}$ & $80 \pm 11$ & $91 \pm 12$ & $173 \pm 13$ & 24 \\
Yes & $229 \pm 15$ & $265 \pm 15$ & $148 \pm 11$ & $292 \pm 21$ & 13 \\
& $\mathrm{p}<0.005$ & $\mathrm{p}<0.005$ & NS & NS & \\
\hline
\end{tabular}

${ }^{*}$ EIUs in different columns are not comparable with each other. ${ }^{+}$Values are mean \pm SEM.

NS $=$ not significant.

seen regarding them all: those with reactive arthritis have higher levels of yersinia specific antibodies. In patients with arthritis the level of yersinia specific secretory IgA was $229 \pm 15$ EIU as compared with $61 \pm 10$ EIU in patients without joint symptoms $(p<0.005)$. The respective values for the molecules with the $J$ chain were $265 \pm 15$ EIU and $80 \pm 11$ EIU $(p<0.005)$. The same tendency was also evident with yersinia specific $\operatorname{IgA} 1$ and $\operatorname{IgA} 2$, but the differences between the two patient groups were not statistically significant (Table 2).

\section{Discussion}

Our results show that the strong IgA-anti-yersinia response characteristic for patients with reactive arthritis after yersinia infection is seen especially clearly in the secretory $\operatorname{IgA}$. The mean concentrations of $\operatorname{IgA}$-anti-yersinia antibodies over the range of samples from each patient show higher values in arthritic patients. The highest concentrations are usually recorded at the beginning of the disease, and the difference is significant. This becomes even more clear later when IgA class antibodies have disappeared from the sera of patients with uncomplicated disease but persist in sera of patients with arthritis. ${ }^{12}{ }^{13}$ The same situation is seen in secretory $\operatorname{IgA}$ class yersinia antibodies and, further, the difference is almost as significant for IgG class antibodies. The persistence and strength of $\operatorname{IgA}$ response in reactive arthritis ${ }^{12} 13$ is in line with observations indicating that in complicated brucella infections high levels of antibrucella antibodies of IgG and IgA class appear. ${ }^{15} 16$ A question arises whether their occurrence is linked to impaired bacterial elimination; circulating $\operatorname{IgA}$ class antibodies have been found to block the bactericidal effect of IgG and IgM antibodies. ${ }^{17} 18$ 
During recent years IgA has been linked in several ways to various rheumatic diseases. In rheumatoid arthritis early appearance of $\operatorname{IgA}$ rheumatoid factor has been reported to indicate a poor prognosis, ${ }^{19}$ and $\operatorname{IgA}$ rheumatoid factor has a close association with fluctuations in disease activity. ${ }^{20}$ Furthermore, raised levels of $\operatorname{Ig} \mathrm{A}$ in the sera of patients with rheumatoid arthritis are frequently seen; some of it is complexed covalently to the $\alpha_{1}$ antitrypsin, a major antiprotease. It has been suggested that production of abnormal thiol reactive IgA may be a critical dysfunction of the humoral immune response in the pathogenesis of rheumatoid arthritis. ${ }^{21}$ Several reports indicate that in ankylosing spondylitis-a disease often linked with reactive arthritis and often seen in persons possessing HLA-B27raised serum $\operatorname{Ig} \mathrm{A}$ levels are seen; $\operatorname{IgA}$ concentrations both in serum and in secretions correlate with the disease activity, and patients with ankylosing spondylitis may also have an increased level of IgA-antiklebsiella antibodies. ${ }^{22-26}$ Recently, increased levels of IgA have been reported also in Reiter's disease in the presence of normal IgG and IgM levels. ${ }^{27}$

Considering all these observations a few facts have to be kept in mind. Firstly, the half life of $\operatorname{IgA}$ is short, only a few days, ${ }^{14}$ and therefore the persistence of antibodies must depend on prolonged synthesis. This raises the question about a persisting antigen or a cross reaction between yersinia and the host structures, possibly HLA-B27. If either of these possibilities were true, the next question would be where the antigenic structure would operate; the site of origin of the antibodies might offer a clue.

The observations by Vuento et al indicate that the increase of $\operatorname{IgA}$-anti-yersinia antibodies is probably not due to increased antibody production by circulating peripheral blood lymphoid cells. ${ }^{28}$ These authors stimulated mononuclear cells from peripheral blood with yersinia or pokeweed mitogen in vitro and measured the various immunoglobulins produced; no difference between patients with or without reactive arthritis could be observed. Nikbin et al also point out that in patients with ankylosing spondylitis no increase in the circulating $\operatorname{IgA}$ bearing lymphocytes is seen despite raised serum $\operatorname{IgA} .^{22}$

Secondly, certain facts about the production of $\operatorname{IgA}$ subclasses and of secretory IgA should be considered. Normally serum IgA consists of 80 $100 \% \operatorname{IgA} 1$ and only $0-20 \% \operatorname{IgA} 2$, whereas mucosal plasma cells produce $\operatorname{IgA} 1$ and $\operatorname{IgA} 2$ in secretions in almost equal amounts. ${ }^{14} 2930$ In secretions the IgA molecules are mainly dimeric, i.e., two IgA monomers are held together by a $J$ chain, to which dimer the secretory component is associated when the molecule passes through the epithelial cells. ${ }^{31}{ }^{32}$ Therefore, the presence of $\operatorname{IgA} 2$ subclass and secretory component in IgA may be considered markers of mucosal origin. ${ }^{33-35}$ Our present and earlier results do not permit a comparison of the $\overrightarrow{\vec{B}}$ absolute amounts of the different $\operatorname{IgA}$ antibodies. $\mathrm{A} \stackrel{+}{+}$ comparison in each category between arthritic and non-arthritic patients is possible, however, and $\bar{c}$ shows an interesting sequence in the statistical $\overrightarrow{\widetilde{D}}$ significances. The groups differ only slightly when 0 the serum concentration of total IgA is compared, $\infty$ but for total secretory IgA the difference is statisti- $\overrightarrow{0}$ cally significant. When specific IgA-anti-yersinia antibodies are compared the patients with arthritis $\vec{\omega}$ have significantly higher values than the nonarthritic ones. ${ }^{11} 12$ If, further, the quite small fractions represented by the yersinia specific antibodies of with $\mathrm{J}$ chain or belonging to secretory $\operatorname{IgA}$ are compared in the two patient groups a highly of significant difference is seen. The fact that $\operatorname{IgM}$ and $\vec{P}$ IgA both contain $\mathrm{J}$ chain should be kept in mind. $\frac{\rho}{\square}$ Since arthritic patients have lower concentrations of $\overrightarrow{ }$ IgM class antibodies to yersinia than the patients without arthritis, ${ }^{13}$ however, it is obvious that the difference in yersinia antibodies containing $\mathrm{J}$ chain $\ddot{\bullet}$ between arthritic and non-arthritic patients is mostly ? due to polymeric IgA antibodies.

The increased and persisting production of $\operatorname{IgA}$ anti-yersinia antibodies is reflected in all categories of IgA studied, but most clearly in secretory IgA. This indicates that at a location close to the $\mathbb{D}$ intestinal mucosa or within it a mechanism must be $\stackrel{2}{\vec{P}}$ operating which chronically stimulates the antibody response and also leads to a leakage of the secretory IgA into the serum; the same or a similar mechanism may also operate at other locations where $\operatorname{IgA}$ is synthesised. This fits well with the fact that yersinia may cause strong stimulation of the lymphoid elements close to the terminal ileum and cecum, and in the mesenteric lymph nodes. ${ }^{36}$

These studies were supported by grants from the Sigrid Jusélius Foundation, the Yrjö Jahnsson Foundation, and the US Public Health Service (No 1 RO 1 AM 33311, awarded by National I Institute of Arthritis, Diabetes, and Digestive and Kidncy Diseases).

\section{References}

1 Toivanen P, Toivanen A, Olkkonen L, Aantaa S. Hospital outbreak of Yersinia enterocolitica infection. Lancet 1973; i: $\omega$ 801-3

2 Leino R, Kalliomäki J L. Yersiniosis as an internal discasc. Ann Intern Med 1974; 81: 458-61.

3 Leirisalo M, Skylv G, Kousa M, et al. Follow up study on $\mathscr{D}$ patients with Reiter's discase and reactive arthritis, with special reference to HLA-B27. Arthritis Rheum 1982; 25: 249-59.

4 Kalliomäki J L, Lcino R. Follow-up studics of joint complications in yersiniosis. Acta Med Scand 1979; 205: 521-5.

5 Mattila L, Granfors K, Toivanen A. Acute anterior uveitis after yersinia infection. Br J Ophthalmol 1982; 66: 209-12.

6 Keat A. Reiter's syndrome and reactive arthritis in perspective $N$ Engl J Med 1983; 309: 1606-15. 
7 Tertti R, Granfors K. Lehtonen O-P, et al. An outbreak of Yersinia pseudotuberculosis infection. J Infect Dis 1984; 149: 245-50.

8 Aho K. Ahvonen P. Lassus A. Sievers K. Tiilikainen A. HL-A 27 in reactive arthritis. A study of yersinia arthritis and Reiter's disease. Arthritis Rheum 1974; 17: 521-6.

9 Leino R, Vuento R, Koskimies S, Viander M. Toivanen A. Depressed lymphocyte transformation by yersinia and Escherichia coli in yersinia arthritis. Ann Rheum Dis 1983; 42: 176-81.

10 Vuento $R$, Leino $R$, Viander $M$, Toivanen $A$. In vitro lymphoproliferative response to yersinia: depressed response in arthritic patients years after yersinia infection. Clin Exp Rheumatol 1983; 1: 219-24.

11 Vuento R, Leino R, Viander M, Toivanen A. Lymphocyte transformation responses to gram negative bacteria after yersinia and salmonella infection: the importance of enterobacterial common antigen for the response. J Rheumatol 1984; 11: $369-72$

12 Granfors K. Measurement of immunoglobulin M (IgM), IgG and IgA antibodies against Yersinia enterocolitica by enzymelinked immunosorbent assay: persistence of serum antibodies during disease. J Clin Microbiol 1979; 9: 336-41.

13 Granfors $\mathrm{K}$, Viljanen $\mathrm{M} \mathrm{K}$, Tiilikainen A. Toivanen A. Persistence of IgM, IgG and IgA antibodies to yersinia in yersinia arthritis. $J$ Infect Dis 1980; 141: 424-9.

14 Hauptman S P, Tomasi T B, Jr. The secretory immune system. In: Stites D P, Stobo J D. Fudenberg H H, Wells J V, eds. Basic and clinical immunology. 5th ed. Los Altos: Lange Medical Publications, 1984: 170-81.

15 Granfors K, Viljanen M K, Toivanen A. Measurement of immunoglobulin $\mathrm{M}$, immunoglobulin $\mathrm{G}$ and immunoglobulin $\mathrm{A}$ antibodies against Yersinia enterocolitica by enzyme-linked immunosorbent assay: comparison of lipopolysaccharide and whole bacterium as antigen. $J$ Clin Microbiol 1981; 14: 6-14.

16 Granfors K, Toivanen A. Diagnosis of human brucellosis with ELISA. Lancet 1982; ii: 668-9.

17 Hall W H, Manion R E, Zinneman H H. Blocking serum lysis of Brucella abortus by hyperimmune rabbit immunoglobulin $\mathrm{A}$. J Immunol 1971; 107: 41-6.

18 McLeod Griffis J. Bactericidal activity of meningococcal antisera. Blocking by $\operatorname{IgA}$ of lytic antibody in human convalescent sera. J Immunol 1975; 114: 1779-84.

19 Teitsson I, Withrington R H. Seifert M H, Valdimarsson H. Prospective study of early rheumatoid arthritis. I. Prognostic value of $\operatorname{IgA}$ rheumatoid factor. Ann Rheum Dis 1984; 43: 673-8.

20 Withrington R H. Teitsson I, Valdimarsson H, Seifert M H. Prospective study of early rheumatoid arthritis. II. Association of rheumatoid factor isotypes with fluctuations in disease activity. Ann Rheum Dis 1984; 43: 679-85.

21 Stanworth D R. IgA dysfunction in rheumatoid arthritis. Immunol Today 1985; 6: 43-5.
22 Nikbin B, Brewerton DA, Byrom $\mathrm{N}$, et al. Lymphocyte function in ankylosing spondylitis. Ann Rheum Dis 1975; 34 (suppl): 49-52.

23 Cowling P. Ebringer R. Ebringer A. Association of inflammation with raised serum $\operatorname{IgA}$ in ankylosing spondylitis. Ann Rheum Dis 1980; 39: 545-9.

24 Calguneri M. Swinburne L. Shinebaum R, Cooke E M. Wright V. Secretory $\operatorname{IgA}$ : immune defence pattern in ankylosing spondylitis and klebsiella. Ann Rheum Dis 1981; 40: 600-4.

25 Trull A K. Ebringer R, Panayi G S. Colthorpe D, James D C O, Ebringer A. IgA antibodies to Klebsiella pneumoniae in ankylosing spondylitis. Scand J Rheumatol 1983; 12: 249-53.

26 Trull A K. Panayi G S. Serum and secretory IgA immune response to Klebsiella pneumoniac in ankylosing spondylitis. Clin Rheumatol 1983: 2: 331-7.

27 Inman R D, Johnson M E A, Klein M H. Immunochemical profiles of $\operatorname{IgA}$ in serum and synovial fluid of Reiter's syndrome (RS). Arthritis Rheum 1985; 28: S58.

28 Vuento R, Eskola J. Leino R, Koskimies S, Viander M. IgM. $\mathrm{IgG}$ and $\mathrm{IgA}$ synthesis in vitro in persons suffering from yersinia arthritis and in patients with ankylosing spondylitis. Ann Rheum Dis 1984: 43: 186-91.

29 Brandtzaeg P. The humoral immune systems of the human gastrointestinal tract. Monogr Allergy 1981; 17: 195-221.

30 Delacroix D L, Dive C, Rambaud J C, Vaerman J P. IgA subclasses in various secretions and in serum. Immunology 1982; 47: 383-5.

31 Brandtzaeg $P$, Prydz $H$. Direct evidence for an integrated function of $\mathrm{J}$ chain and secretory component in epithelial transport of immunoglobulins. Nature $1984 ; 311$ : 71-3.

32 Crago S S, Kutteh W H. Moro I. et al. Distribution of IgAl-, IgA2-, and $\mathrm{J}$ chain-containing cells in human tissues. J Immunol 1984; 132: 16-8.

33 André C. André F, Fargier M C. Distribution of $\operatorname{IgA} 1$ and $\operatorname{IgA} 2$ plasma cells in various normal human tissues and in the jejunum of plasma IgA-deficient patients. Clin Exp Immunol 1978; 33: 327-31.

34 André C. Berthoux F C. André F, Gillon J, Genin C, Sabaticr J C. Prevalence of IgA2 deposits in IgA nephropathies. $N$ Engl $J$ Med 1980; 303: 1343-6.

35 Brown T A, Murphy B R, Radl J, Haaijman J J, Mestecky J. Subclass distribution and molecular form of immunoglobulin $A$ hemagglutinin antibodies in sera and nasal secretions after experimental secondary infection with influenza $A$ virus in humans. J Clin Microbiol 1985; 22: 259-64.

36 Ahlqvist J, Ahvonen P. Räsänen J A. Wallgren G R. Enteric infection with Yersinia enterocolitica. Large pyroninophilic cell reaction in mesenteric lymph nodes associated with early production of specific antibodies. Acta Pathol Microbiol Immunol Scand [A] 1971; 79: 109-22. 